\title{
Environmental necrophagous fauna selection in a funerary hypogeal context: the putridarium of the Franciscan monastery of Azzio (Northern Italy)
}

Pradelli J. ${ }^{1,}$ Rossetti C. ${ }^{2}$, Tuccia $\mathrm{F}^{1}$., Giordani $\mathrm{G}^{1}$., Licata $\mathrm{M}^{2}$., Birkhoff $\mathrm{J}^{\mathrm{M}}{ }^{3}$., Verzeletti $A^{4}$, Vanin $S^{1}$.

1. School of Applied Sciences, University of Huddersfield, Queensgate, HD1 3DH, Huddersfield, UK

2. Centre of Research in Osteoarchaeology and Paleopathology, Department of Biotechnology and Life Science, University of Insubria, Varese, v. O. Rossi, 9, 21100 Varese, Italy

3. Department of Biotechnology and Life Science, University of Insubria, Varese, v. O. Rossi, 9, 21100 Varese, Italy

4. Department of Medical and Surgical Specialities, Radiological Sciences and Public Health, University of Brescia, P.le Spedali Civili, 1, 25100, Brescia, Italy.

\begin{abstract}
Insects play a fundamental role in the removal and recycling of the organic matter from human cadavers and animal carcasses. Several factors can affect both the cadaver decomposition and colonisation by insects and other animals. Accessibility to the body is one of these factors. The archaeological, anthropological and entomological investigations conducted inside the Crypt of the Franciscan Monastery in Azzio (Varese, northern Italy) allowed the reconstitution of the funerary practices used by a Franciscan community between the $17^{\text {th }}$ and $18^{\text {th }}$ centuries and provides a good example of necrophagous entomo-fauna selection. Human remains were found in the putridarium chamber, a semicircular room with sixteen narrow and semicircular niches, where bodies were located untill the complete decomposition of the soft tissues. Numerous puparia were collected from the bones, the clothes and the niche walls. The majority belonged to Hydrotaea capensis (Diptera: Muscidae) and a few puparia of scuttle flies in the family Phoridae were detected among the studied material. Fragments of beetles in the families Staphylinidae and Cryptophagidae were also sampled. The entomological findings clearly support the hypothesis that the bodies were quickly transferred into the crypt after death and that the specific hypogeal
\end{abstract}


(subterranean) environment selected the entomofauna community composition. The observations here reported with similar entomological findings cited in the literature support the hypothesis of a specific selectivity on insects' community by underground environments (e.g. graves, crypts). This conclusion can be applied to outline a common pattern in archaeological contexts and in indoor forensic cases.

\section{Keywords}

Funerary Archaeoentomology, Forensic Entomology, Hydrotaea capensis, necrophagous insects, hypogeous fauna

\section{Introduction}

The colonization of a cadaver after death by insects is affected by several factors, some depending on the cadaver itself but more so on the environment and the time of the year, i.e. the season (Campobasso et al., 2001). From an ecological and biological point of view, a species' seasonal activity (phenology), its distribution and habitat preferences are the key factors influencing the composition and structure of the communities colonizing a body. The above-mentioned factors affect the structure of community exploiting the body, thus creating a complex food-web.

The accessibility to the body is another factor to be considered because it has an indirect and a direct effect on the necrofauna (insects' community which has the dead body as an ecological niche). The indirect effect is related with the dispersion of the volatile organic compounds (VOCs) and the microbial volatile organic compounds (MVOCs) that act as attractants for necrophagous and necrophilous insects (Diptera, Coleoptera, and Lepidoptera) and other scavengers (e.g. birds and mammals). Furthermore, some of these molecules are inducing the oviposition of flies (Verheggen et al., 2017; Davis et al., 2013). Body accessibility also directly selects the species able to bypass the physical barriers due to their behavior (e.g. ability of digging) or their size allowing them to pass through small holes, cracks, and fissures. As demonstrated by Bhadra et al. (2014), first instar larvae are able to colonise a body concealed inside a suitcase, emerging from eggs laid externally on the zip and passing through the small gaps. 
In the forensic and archaeo-funerary contexts, the evaluation of the body accessibility is particularly important and it needs a deep consideration in order to reconstruct historical events. Both archaeological and forensic investigation are based on evidence collected in the present to reconstruct what happened hours, days, months or years before the site or the crime scene are discovered and investigated.

Necrophagous insects are specialized on the consumption of decaying organic matter, which includes dead tissues from humans and animals regardless of their state of preservation (Huchet et al. 2013a, b).

One core-idea in the entomological evaluation of a cadaver is that necrophagous insect colonisation follows specific and predictable patterns depending on their biology and on their food preferences, related to the availability of food during the different stages of decomposition (Smith, 1986). This has been demonstrated and verified by several authors despite some anomalies due to environmental variability (Wiss and Cherix, 2013). In buried remains, or in cases where the body is in a sheltered location (e.g. indoors, coffins, crypts, etc), colonisation pattern is completely different compared to the colonisation from that which occurs in open environments. It is characterized by the presence of a limited number of species or by the dominance of some of them (e.g. coffin flies in the Phoridae family (Campobasso et al., 2004; Bugelli et al., 2015; Goff, 1991; Reibe and Madea, 2010a; Trumble and Pienkowski, 1979; Dirrigl and Greenberg, 1995; Pastula and Merritt, 2013), and species in the genus Hydrotaea in the Muscidae family (Giordani et al., 2018; Gunn and Bird, 2011; Morrow et al., 2015; Vanin, 2012)). Previous studies have investigated the entomo-fauna associated with mummified or partially mummified bodies, inarchaeological contexts. A majority of these studies focus on corpses found in enclosed hypogeal environments, sealed indoor places below the ground level (e.g. crypts and collapsed trenches), provide interesting results concerning the selectivity of these specific environments on the insects' community (Huchet, 2014; Huchet et al., 2013a, 2013b; Vanin, 2012; Fornaciari, 2018; Fornaciari et al., 2009; Masetti et al., 2008; Bourel et al., 2004; Nystrom et al., 2005). In such contexts, traces of the insect's colonisation could still be detected in the form of Coleoptera adult fragments or Diptera puparia (the post-feeding third larval cuticle undergoes several chemical reactions, eventually turning into a hard outer case called puparium (Martín-Vega et al., 2016)), and only occasionally other insect adults fragments (Panagiotakopulu, 2001; Panagiotakopulu, 2004; Panagiotakopulu and Buckland, 2012; Vanin et al., 2009). The particularly hard exoskeleton of Coleoptera 
species and the external chitinised cuticle of Diptera puparia (Vanin and Huchet, 2017; Panagiotakopulu, 2004, 2001; Panagiotakopulu et al., 2012; Huchet, 2014) are very resistant to mechanical decay and they may be preserved for an extended period of time (e.g.: centuries).

In this paper a putridarium in the Lombardy region of Northern Italy, is examined from an entomological perspective in order to describe how a hypogeal closed environment can strongly select the entomo-fauna associated with human decomposition and to verify some hypotheses related to the time of interment and about the funerary practices among the Catholic clergy communities in the $17^{\text {th }}-18^{\text {th }}$ centuries: were the bodies exposed for a long time before inhumation or not? This is the first time that insects collected from this kind of environment are analysed and the resulting community described.

\section{Historical context}

A peculiar funerary chamber called putridarium, usually placed in the underground crypts of Catholic Churches, was a typical burial custom from the $16^{\text {th }}$ until the early $20^{\text {th }}$ century in some Italian monasteries. This fascinating funerary practice consisted of two separate burial phases in order to prepare the body to the "afterlife journey" (Fornaciari et al., 2010).

The putridarium consisted of a hypogeal room with special structures named cola from the Latin colum, drainer - with the function of facilitating the decomposition and draining the body fluids. Two different kinds of cola are known: the sitting and the horizontal cola. Sitting cola consisted of a masonry structure placed within niches along the putridarium wall, usually of elliptic or semicircular shape. Each niche had a wooden seat with a hole in the middle connected to drainage canals. In this case, soon after the death, the corpses were placed in a seated position on the cola until skeletonisation. Then, the remaining bones were transferred into the secondary burial: the ossuary, ossarium. This practice was performed exclusively on members of religious orders, like priests, friars or nuns (Fornaciari et al, 2010).

Several papers examine these distinctive interments from an anthropological and historical point of view, the majority of them refers to putridaria located in Southern Italy (Amadei and Fornaciari, 1995; Fabbri, 2001; Farella, 1982; Pezzini, 2006).

\section{Archaeological Context}


During renovation inside the Franciscan Monastery of Azzio (Northern Italy) (Fig. 1) a crypt was discovered. Preliminary archaeological excavations of the crypt revealed the presence of a putridarium, a hypogeal elliptical room $(3.70 \times 2.95 \mathrm{~m})$ with a vaulted ceiling and with sixteen narrow and semi-circular niches with a seat (sitting cola). Twelve of them preserved bone remains whereas the other four were empty. Along with human bones, desiccated tissues, fragments of fabrics and wood fragments were collected. According to the preliminary anthropological analysis, the skeletal remains belonged to adult males: the estimated average height was near $165 \mathrm{~cm}$ and the age at death was 40-50 years (Licata and Rossetti, 2017). In every niche many entomological remains were observed and sampled, some of them were attached to human bones and clothes and others were gathered at specific locations on the floor (Fig. 2). 


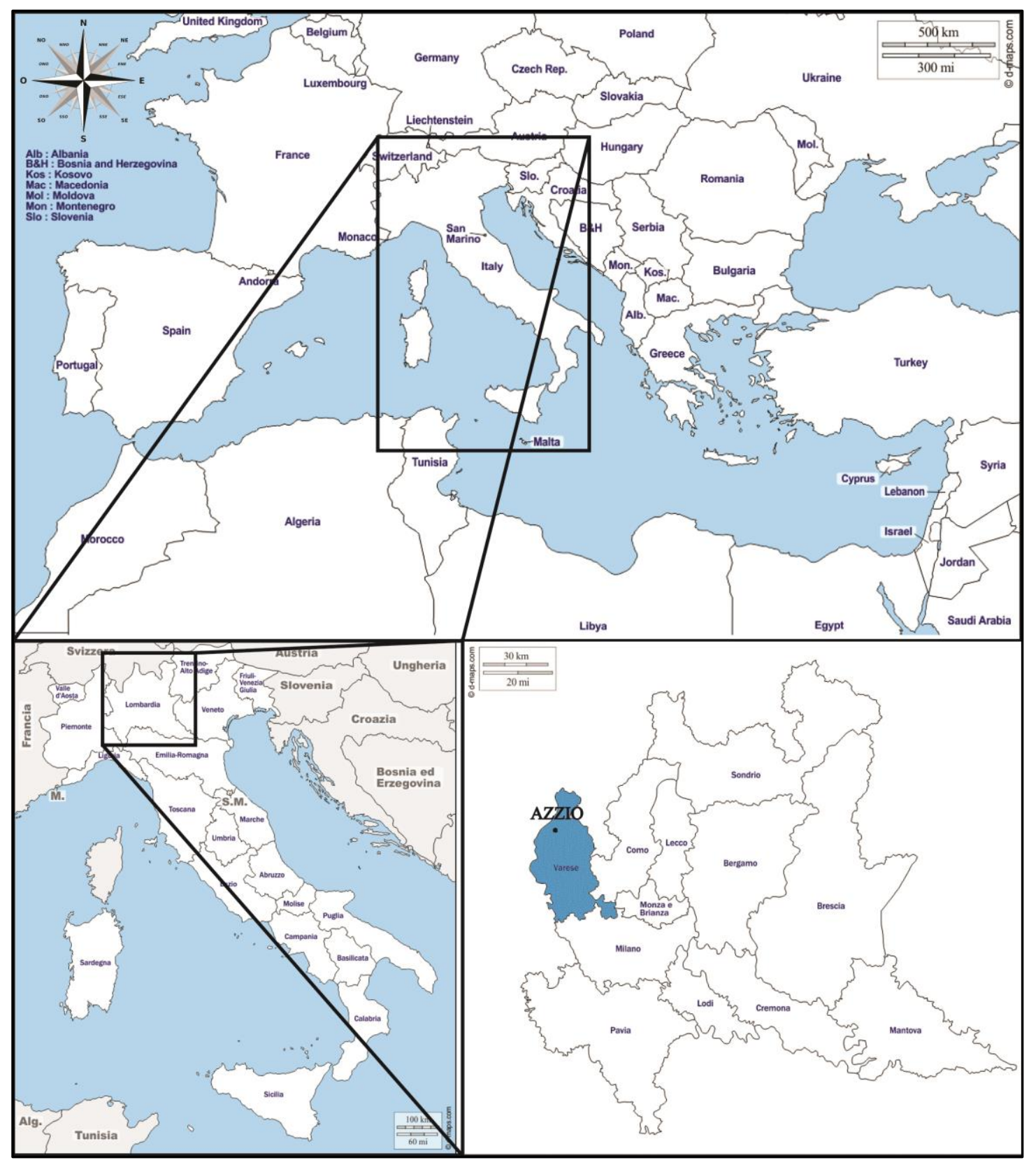

Fig 1: Map of the Meditterranean Area. The black dot indicates the Monastery location. Azzio is located in Lombardy region (Italy), as part of Varese province $\left(45^{\circ} 53^{\prime} \mathrm{N} 8^{\circ} 42^{\prime} \mathrm{E}\right)$ (maps used for the plate retrieved from https://dmaps.com/index.php?lang=en) 


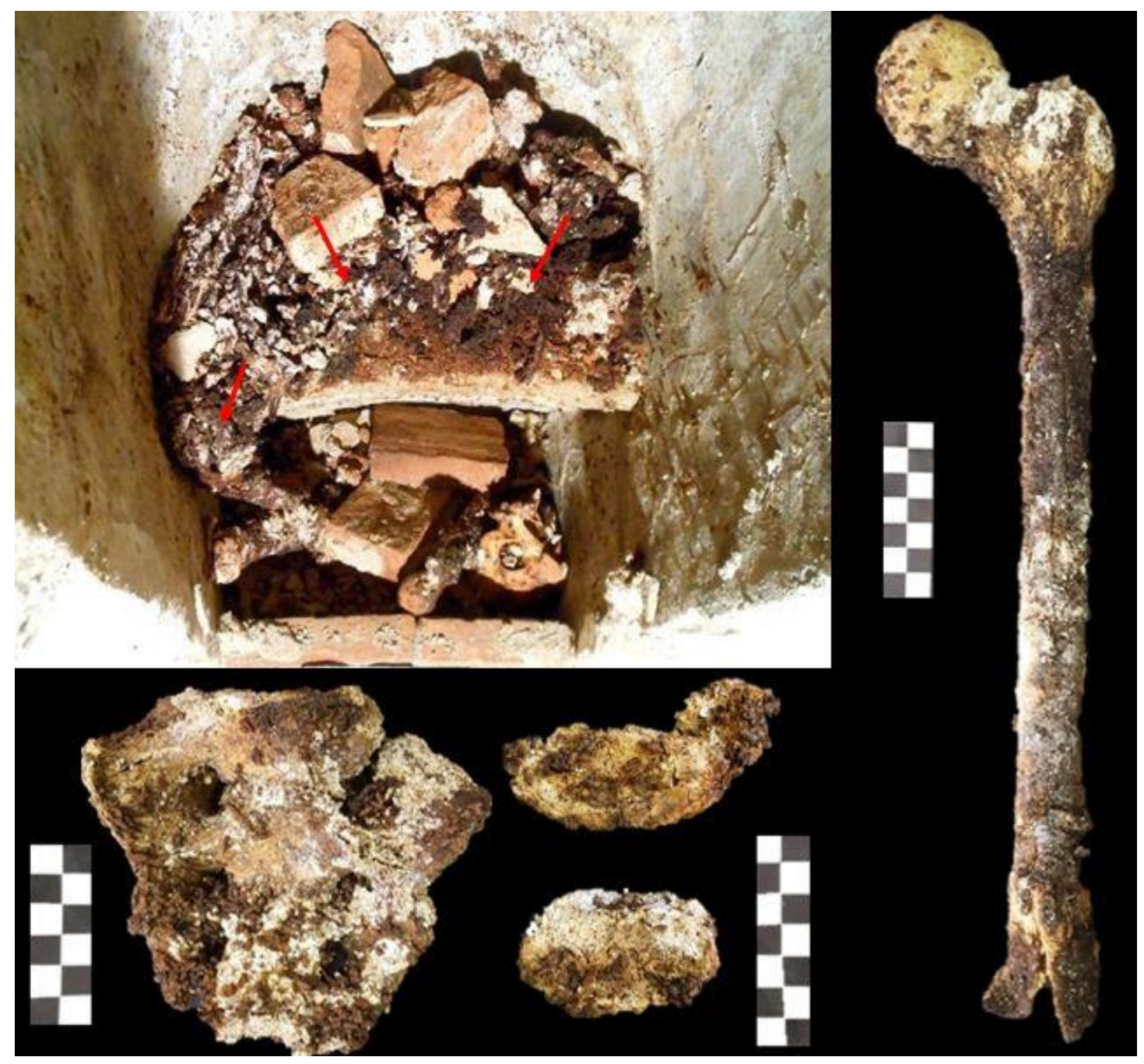

Fig. 2: One of the niches of the putridarium of the Franciscan Monastery of Azzio (Northern Italy) used from $17^{\text {th }}$ to the $18^{\text {th }}$ centuries. Red arrows indicate the sampling location inside a niche. Bones with encrusted entomological remains (photos Licata M.) (Scale bar: each white or black square is $1 \times 1 \mathrm{~cm}$ ).

\section{Materials and Methods}

Five small clumps consisting of different size puparia held together by a mortar of desiccated putrefactive fluids and soils were collected on the floor of each niche (Fig. $3)$. The average weight of the clumps was of $6.3+/-0.9 \mathrm{~g}$. 


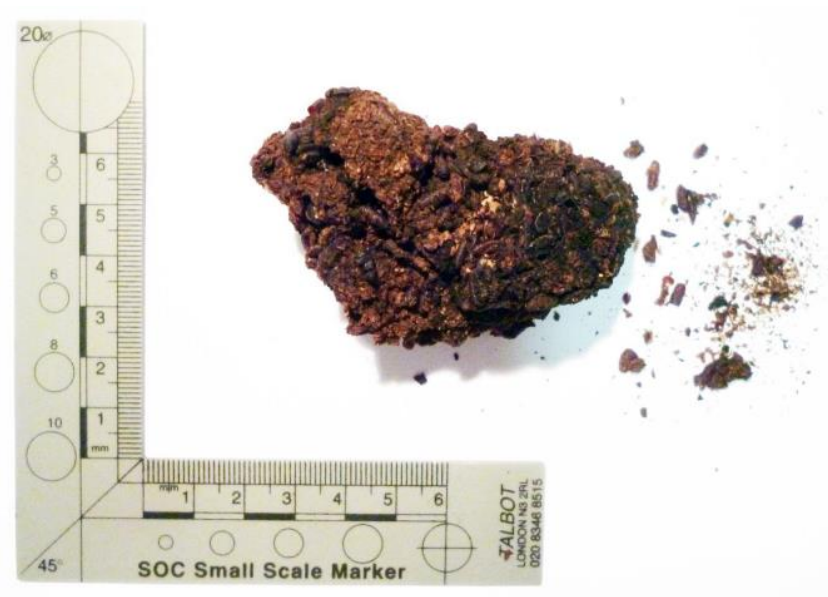

Fig. 3: Puparia clump collected from one of the niches in the crypt of the Franciscan Monastery of Azzio (Northern Italy).

The samples were stored initially in a dry condition until the entomological analyses were performed.

Due to the unusual appearance of the samples, a cleaning process had to be performed in order to make the morphological characters of the insect fragments visible thus allowing the species identification. The clumps were immersed overnight in a solution of warm water and soap. This first step was necessary for the puparia to be released from the mortar of putrefactive fluids. Then, the puparia were carefully washed with distilled water and placed in a $20 \% \mathrm{NaOH}$ solution to remove the organic residues (Sukontason et al., 2007). For particularly encrusted samples, two additional steps were performed. Firstly, the samples were individually sonicated for 15 seconds using a sonicator bath $(\mathrm{QH}$. Kerry Ultrasonic Limited, $\mathrm{f}=50 \mathrm{~Hz})$ and secondly, a wet paintbrush doused with glacial acetic acid was used to clean the external surface of puparia from the residual soiling. At the end of these procedures, the samples were airdried.

Microscopic observations were performed using a Leica DM500 microscope and microphotographs were taken using a Keyence VHX-S90BE digital microscope, equipped with Keyence VH-Z250R and VH-Z20R lens and VHX-2000 Ver.2.2.3.2 software (Keyence). In addition, the smallest puparia, after the cleaning process, were mounted on stubs with conductive adhesive tape and coated with Au-Pd in a SC7620 Mini Sputter Coater (Quorum Technologies, UK) and observed with a FEI QUANTA 650 FEG SEM (Thermo Scientific, USA). Pictures at high quality were directly 
digitized from the Scanning electron microscope (SEM).

The majority of Diptera were identified using specific taxonomic keys (Giordani et al. 2018; Skidmore, 1985; Disney, 1994) whereas the Coleoptera fragments were identified by comparison with one of the authors (SV) collection of specimens previously identified.

An estimation of the minimum number of individuals has been performed by weighing and counting small quantities of cleaned dipterous puparia. The exact numbers are not provided due to the very high numbers of individuals and due to the degree of homogeneity of the samples. As only a brief entomological sampling has been performed, five clumps cannot be used to represent a complete overview of insects' quantity in this specific context. Furthermore, the minimum number of individuals is not relevant to the objectives of the presented paper.

\section{Results}

The clumps were composed almost entirely of dipterous puparia belonging to two families: Muscidae and Phoridae (Figg. 4, 5). Muscidae family was represented only by the species Hydrotaea capensis (Wiedemann, 1818) whereas the Phoridae puparia were not identified at the species level due to the lack of specific literature as further discussed.

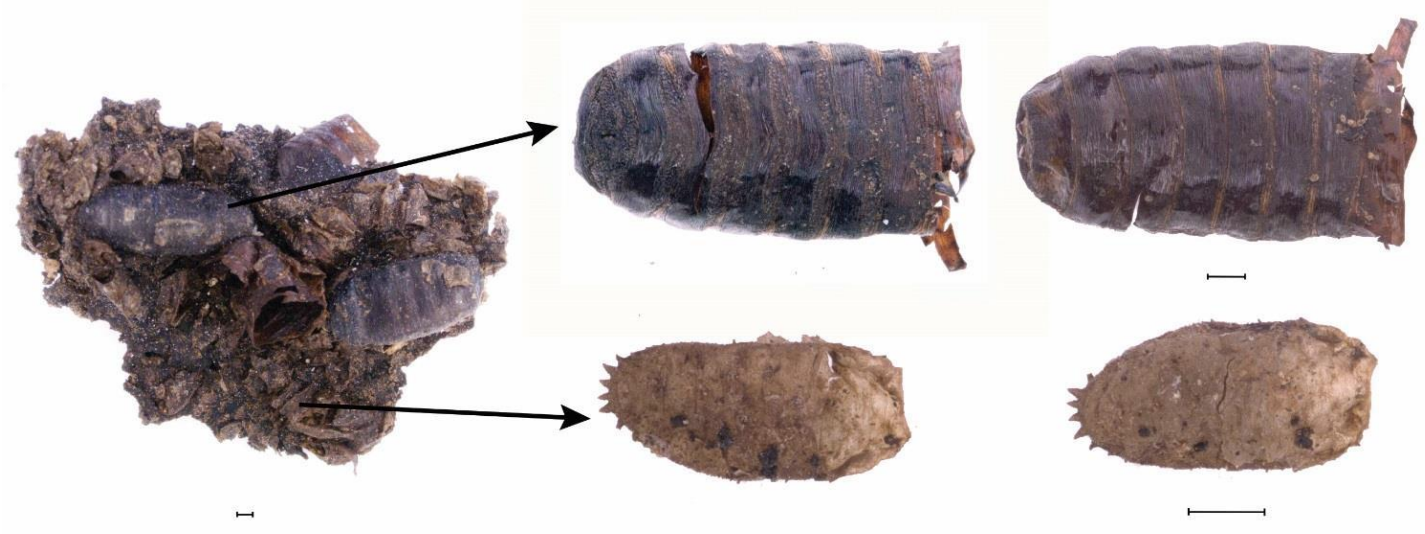

Fig. 4: Fragment of a clump with detailed Muscidae (upper) and Phoridae (lower) puparia (Scale bar: $500 \mu \mathrm{m}$ ). 


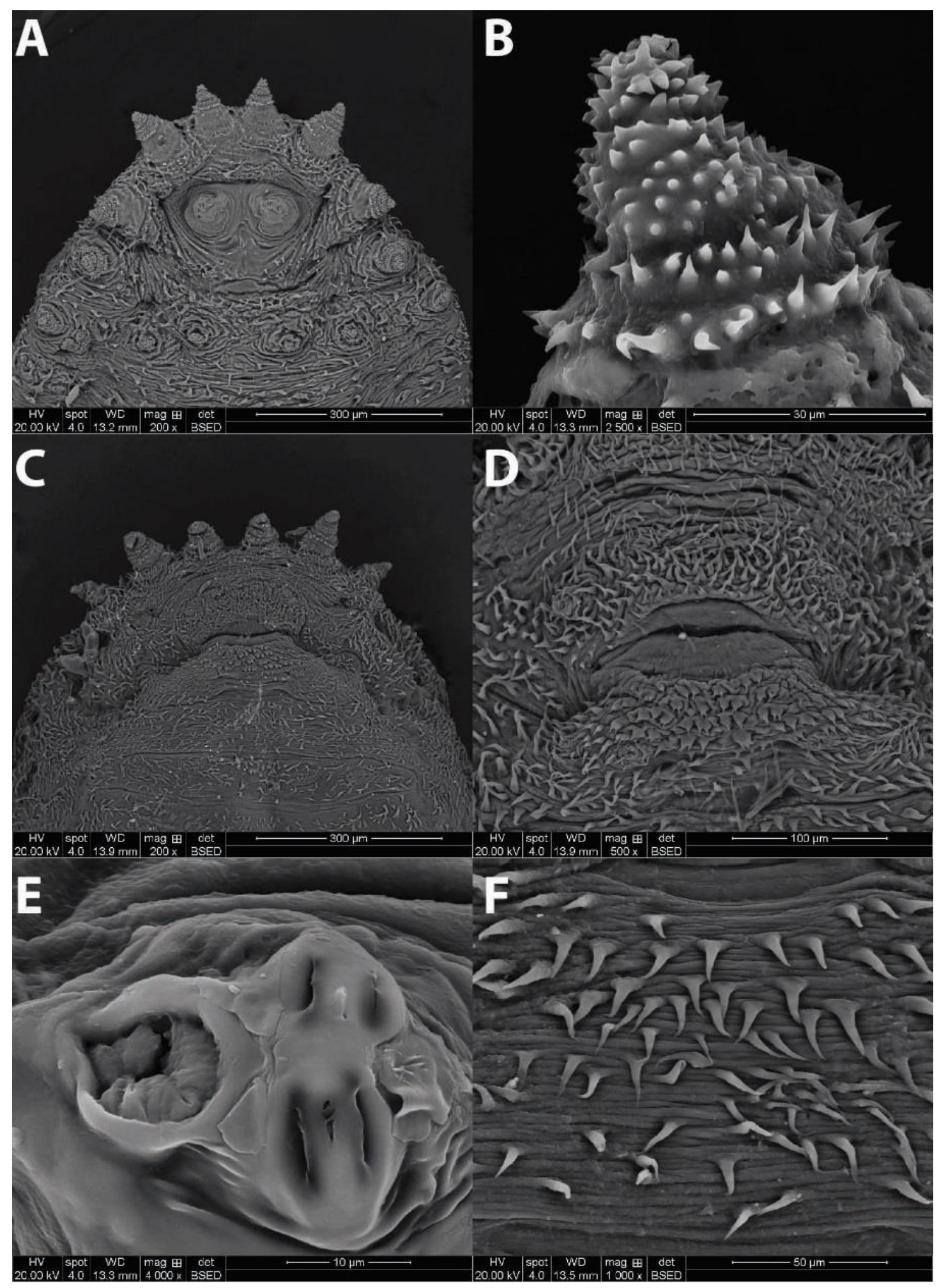

Fig.5: Phoridae puparia (SEM); A) posterior region-dorsal view, B) detail of the papilla, C) posterior region-ventral view, D) anal plate, E) posterior spiracle, F)intersegmental spines (Scale bars are reported in each frame).

Mite (Acarina) remains were detected on an $H$. capensis puparium but not further identified (Fig. 6). 
Among the Coleoptera, remains of elytra, pronotum, and heads of rove beetles (Staphylinidae) were collected. Some fragments were identified as belonging to a species in the genus Quedius Casey, 1915. In addition, a partially complete specimen of Cryptophagidae, Cryptophagus montanus C. Brisout de Barneville, 1863 was also collected (Tab. 1, Fig. 7).

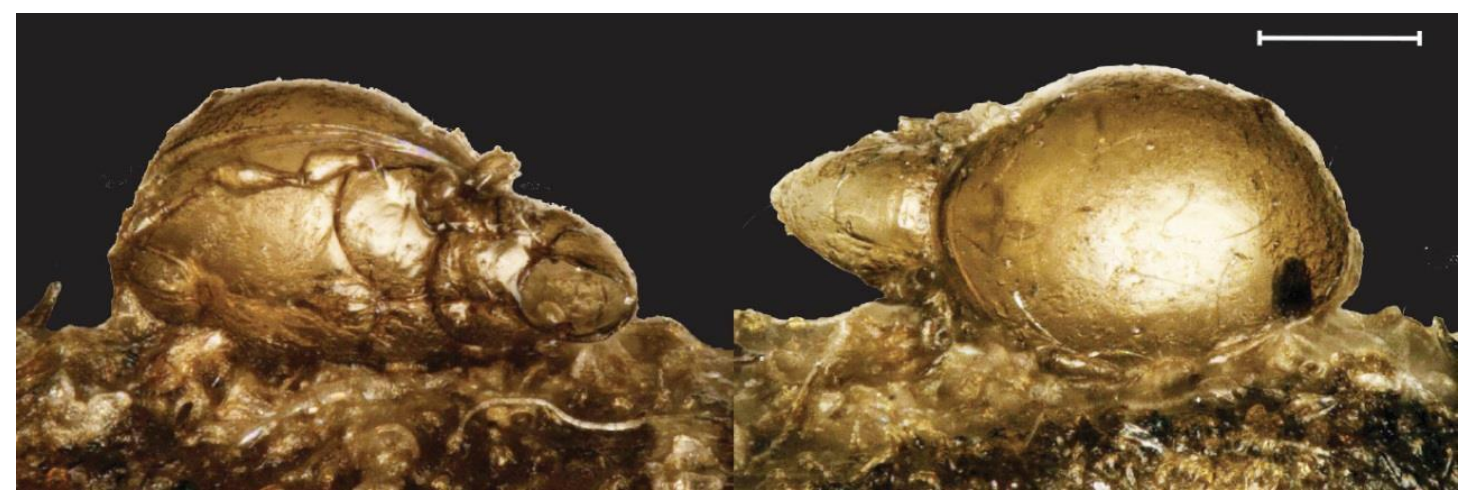

Fig. 6: Mite in ventral (left) and dorsal (right) view. The specimen was found on the puparium cuticle of a Hydrotaea (Scale bar: $100 \mu \mathrm{m}$ ). 

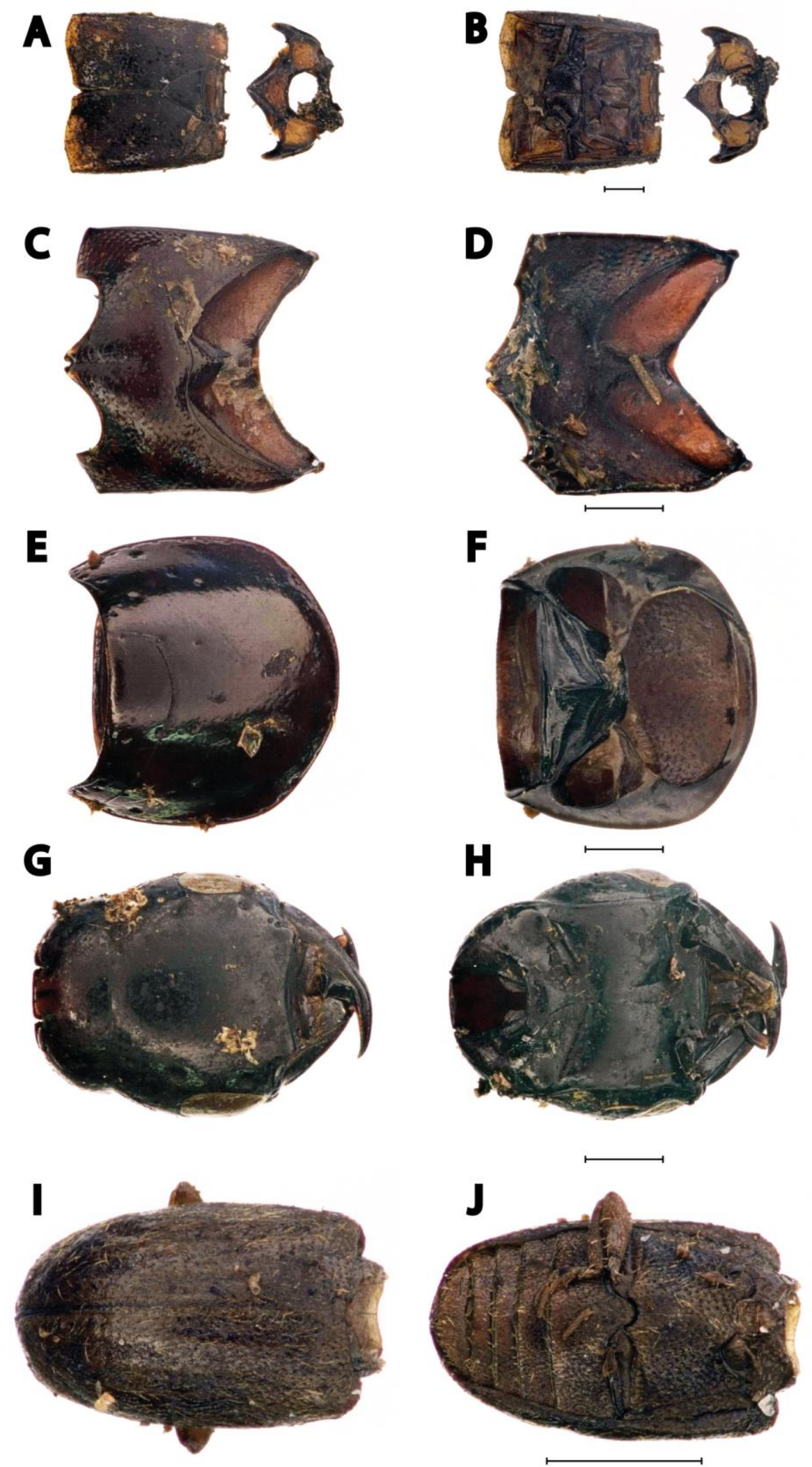

Fig. 7: Coleoptera fragments from the crypt of the Franciscan Monastery of Azzio (Northern Italy). A, B, C, D) fragments of unidentified rove beetles (Staphylinidae); E, F, G, H) fragments of Quedius sp. (Staphylinidae); I, J) incomplete specimen of Cryptophagus montanus (Cryptophagidae) (Scale bar: $500 \mu \mathrm{m})$. 
Tab. 1 Summary of the entomological samples collected from the putridarium of the Franciscan Monastery of Azzio (Northern Italy) $(\mathrm{A}=$ adult; $\mathrm{Pu}=$ puparia; $*=1-10$, $* *=10-100 * * *=100-1000 ; * * * *=>1000)$.

\begin{tabular}{lcc}
\hline Taxon & $\begin{array}{c}\text { Developmental } \\
\text { stage }\end{array}$ & $\begin{array}{c}\text { Minimum } \\
\text { number of } \\
\text { individuals }\end{array}$ \\
\hline Diptera, Muscidae & & \\
\hline Hydrotaea capensis & $\mathrm{Pu}$ & $* * * *$ \\
\hline Diptera, Phoridae & $\mathrm{Pu}$ & $* * *$ \\
\hline Gen. sp. & & $*$ \\
\hline Coleoptera, Staphylinidae & $\mathrm{A}$ & $*$ \\
\hline Quedius sp. & $\mathrm{A}$ & \\
\hline Gen. sp. & & $*$ \\
\hline Coleoptera,Cryptophagidae & $\mathrm{L}$ & \\
\hline Cryptophagus montanus & & $*$ \\
\hline Acarina & $\mathrm{A}$ & \\
\hline Gen. sp. & & \\
\hline
\end{tabular}

\section{Muscidae}

Muscidae are commonly known as house flies or stable flies. Their size ranges from 2 to $14 \mathrm{~mm}$. Their body is usually bristly, with colour varying from yellow to grey or black, but some species are metallic blue or green. Muscidae have a worldwide distribution and the family contains almost 4,000 described species in over 100 genera (Gregor et al., 2002). Most species are synanthropic with larvae occurring in many different habitats, from dung and decaying plant matter to carrion and fungi. Muscidae can be also parasites of other insects and vertebrates but also predators of other insect larvae or other invertebrates (Skidmore, 1985).

Muscidae includes several significant taxa active during different stages of decomposition such as Musca Linnaeus, 1758, Muscina Fallén, 1817, Synthesomia Brauer \& von Bergenstamm, 1893 and Hydrotaea Linnaeus, 1758 (Smith, 1986; Lo Pinto et al., 2017; Giordani et al., 2018; Grzywacz et al., 2013, 2014, 2017a, 2017b; Huckett, 1954).

\section{Genus Hydrotaea}

Species in the Hydrotaea genus, commonly known as dump flies, are frequently recorded from buried corpses (Mégnin, 1894; Bourel et al., 2004; Giordani et al, 2018). 
Puparia and fragments of adults belonging to this genus were collected during archaeological excavations of graves from different periods (Huchet, 1996, 2010, 2014 , 2013), and also from mummies (Couri et al., 2009; Palla et al., 2011) and collapsed war trenches (Huchet, 2013). Larvae primarily feed on carrion, however, they can also exhibit predatory behavior on other fly larvae when food availability is low (Morrow et al., 2015, 2016). Hydrotaea flies usually appear during the ammoniacal fermentation stage of decomposition in exposed carrion (Turchetto and Vanin, 2004; Couri et al., 2009). However,there is not a clear indication when these flies start colonising buried bodies.

In the putridarium's material, a single species representing the majority of the entomological material was found: Hydrotaea capensis. It is a synanthropic summer species native of the old world, recorded in various habitats from forests to open field (Grzywacz et al., 2017). The species is reported both from archaeological context and forensic cases all over Europe (Greenberg, 1985; Huchet, 2013; Giordani et al., 2018). It belongs to the colonizer group that arrives during the advanced decomposition stage of cadavers in exposed environments. However, it could appear as the first colonizer when the cadaver is concealed or buried due to the absence of competition with blowflies and flesh flies (Smith, 1986; Huchet, 2013). In these cases, Hydrotaea capensisis is the main or the only taxon present on the body (Huchet, 2013; Vanin, 2012; Turchetto and Vanin, 2004). Puparia of this species are detailed by Giordani et al. (2018) and they are characterised by the presence of visible arcuate respiratory horns on the dorsal side.

\section{Phoridae}

Phoridae are commonly known as scuttle or coffin flies and it is one of the largest family among Diptera. They are distributed worldwide with approximately 245 described genera and over 3,000 species (Disney, 1994, 1989). Species in this family are generally very small with a length ranging from 0.5 to $6.0 \mathrm{~mm}$. The thorax shows the characteristic hump-backed appearance and wings have a peculiar venation (Fig. 8). 


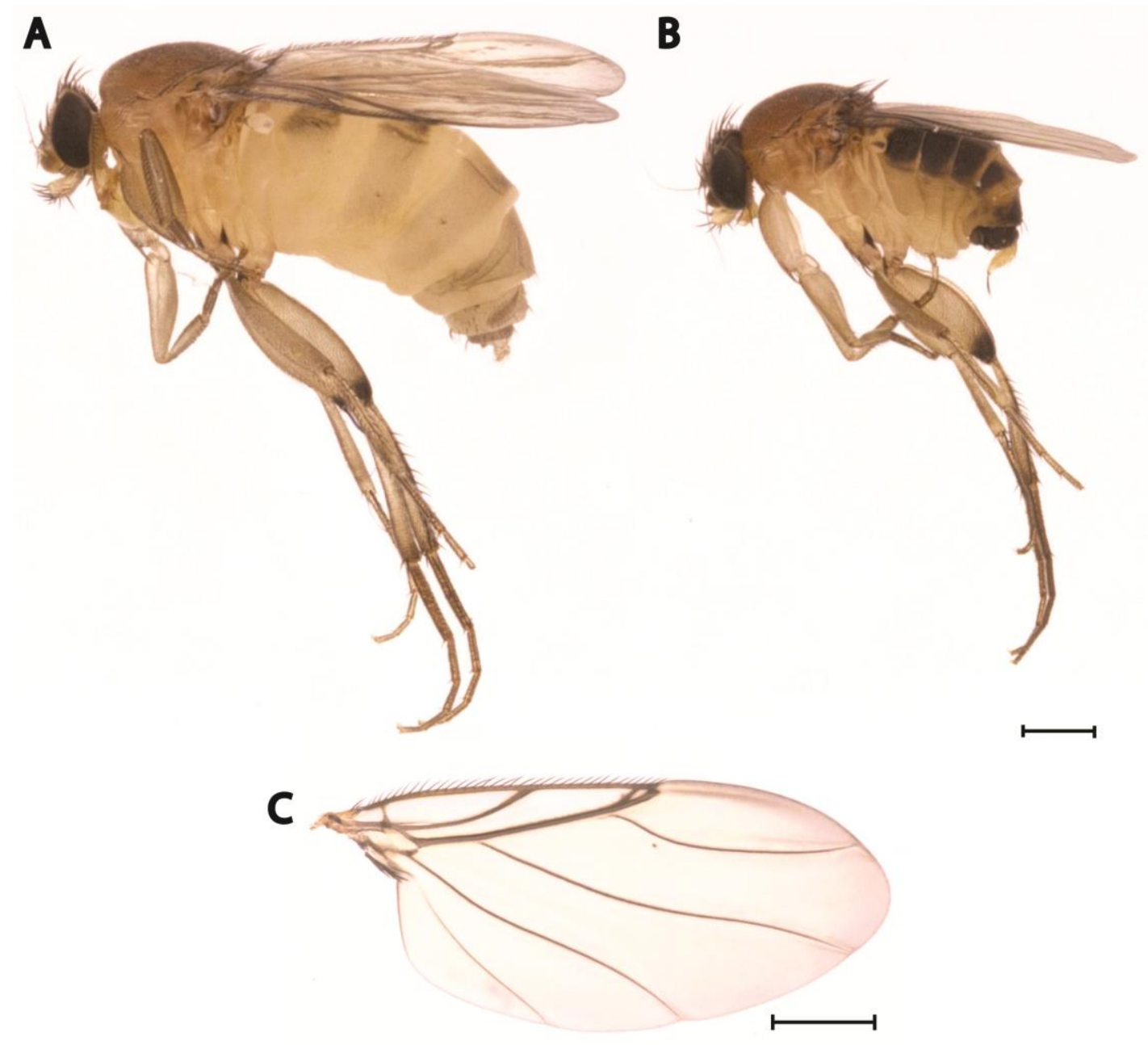

Fig. 8: The characteristic hump-backed appearance of a Phoridae fly Megaselia scalaris Loew, 1866 -Female (A) and male (B) - and wings venation (C) (Scale bar: $500 \mu \mathrm{m}$ ).

Adults are commonly found around decaying vegetation or animal matter, and some species are parasites of ants, termites and bees, beetles, caterpillars, millipedes and land mollusks (Disney, 2008). Larval feeding habits are varied: from fungi to plants to other arthropods.

Scuttle flies are reported from several burials (Amendt et al., 2010) and are often the dominant taxon in this context (Campobasso et al., 2004; Martin-Vega et al. 2011) thanks to the ability of adults to move to significant depths through the soil (Disney, 1994). The lack of identification keys and the lack of detailed descriptions for the puparia of species in this family (Feng and Liu, 2012 a, 2012b; Greenberg and Wells, 1998; Sukontason et al., 2006) prevented the identification of the specimens to the species level. However, through comparison with previously sampled specimens, it is possible to tentatively ascribe them to a species in the genus Conicera Meigen, 1830, but further morphological analyses and comparison would need to be performed to 
confirm this. In this context, attempts at molecular identification were inconclusive, potentially due to DNA degradation as a result of the high bacterial charge during and after the decomposition process and the potential presence of PCR inhibitors.

\section{Staphylinidae}

Staphylinidae are characterised by their short elytra that leave more than half of their abdomens exposed (Betz et al.; 2018, Blackwelder, 1936). There is considerable variation among the species with the size ranging from less than 1 to $35 \mathrm{~mm}$ (Newton, 1990). Larvae are campodeiform with a heavily sclerotized head (Lohse, 1964, 1974). The majority of the species in this taxon are predators of insects and other kinds of invertebrates, but their diet might include fungi spores and pollen. Species in this family inhabit various ecological niches: from slightly wet environments, such as forest leaf litter and similar kinds of decaying plant matter, to ant nests, fungi, dung, and carrion (Bohac, 1999). With approximately 58,000 species, the taxon is currently recognized as the largest family of Coleoptera and the classification of the many species is controversial (Blackwelder, 1936).

Some species of rove beetles are reported from carcasses and cadavers although the majority of them are not carrion feeders but mainly larvae predator (e.g. Creophilus maxillosus (Linnaeus, 1758)) and only a few species are strictly necrophagous (e.g. Philonthus varians (Paykull, 1789) (Pushkin, 2015)).

\section{Cryptophagidae}

Cryptophagidae are commonly known as silken fungus beetles and are characterized by oval body shape (Kirkby, 1826). The family is composed of small beetles ranging between 1 to $11 \mathrm{~mm}$. At the present, around 1,000 species are described worldwide divided into almost 60 genera. Although a cosmopolitan family, it is more frequent in forests environments (Leschen, 1996). Cryptophagids are microphagous and they are commonly present in decaying habitats with fungal growth, such as rotting wood, leaf litter, stored products, nests of mammals and social insects and only rarely have been reported from human bodies (Leschen, 1996; Pushkin, 2015; Kočárek, 2003; Panagiotakopulu and Buckland, 2012; Easton and Smith, 1970).

\section{Discussion}

The findings of typical hypogeous species and the absence of species typical of 
colonisation of exposed bodies suggest a complete decomposition occurred in the putridarium room. All the dipterous species collected are frequently recorded as main colonisers of buried bodies or indoor cases, where the accessibility to the body is restricted (Amendt et al, 2010; Bugelli et al., 2015; Vanin, 2012). In this specific case, the putridarium entrance is located in front of the Church main altar. The trap door consisted of a heavy stone without any other kind of sealing or pointing (e.g.: bitumen, concrete, etc). This loose-fit stone does not prevent the passage of insect species of small size (Fig. 8), adapted to colonise buried bodies, as previously mentioned. These species can dig through small fissures and cracks; in some cases, adults lay eggs at the entrance of crannies allowing larvae to reach the food source. Hence, it is reasonable to assume that immediately after the death, the bodies were prepared and placed in the crypt, preventing colonisation from larger species commonly present in exposed bodies, such as the blue and green blow-flies in the genera Calliphora RobineauDesvoidy, 1830 and Lucilia Robineau-Desvoidy, 1830 (Diptera, Calliphoridae). This statement is supported by the work published by Reibe and Madea 2010a on the specific colonisation in indoor cases (Bugelli et al, 2015; Reibe and Madea, 2010b). In other archaeological contexts, as for example, the mummies found under the church of Roccapelago (Central Italy) where some openings (small windows) were present, the entomo-fauna associated with the mummified bodies are reported as more diverse (Vanin, 2012). In fact, in the Roccapelago crypt, species in the families Calliphoridae, Sarcophagidae, Fanniidae, and Heleomyzidae were found. The absence of all these taxa on the Azzio sampling confirms that the crypt was isolated and that the trap door was not frequently opened.

As shown by Campobasso et al. (2004) and Martín-Vega et al. (2011), it is not unusual to find, in burials of cadavers with restricted access, a low number of species with several generations generating a large number of specimens. The association between Hydrotaea capensis and species in the family Phoridae in burial contexts is well documented by Bourel et al (2004). They reported that, on 22 exhumations performed in Northern France, H. capensis was collected 15 times in association with a high quantity of Conicera tibialis Schmitz, 1925. Therefore, the species belonging to the Phoridae family, which were tentatively identified as Conicera, might be plausible.

The staphylinids collected in the putridarium feed mainly on flies' immature stages such as larvae. The low number of specimens collectedmay be considered as further confirmation that the crypt was not easily accessible, however, high vagility cannot be 
excluded.

\section{Conclusion}

In this paper, a peculiar environment "the putridarium" was investigated from an entomological point of view in order to evaluate if the bodies were interred suddenly after the death or exposed for a long period before inhumation. Insects showed that bodies were placed in the putridarium shortly after the death, due to the exclusive presence of species typical of burial/hypogeal contexts and the absence of any species typical of the exposed body colonisation, supporting the archaeological and historical records of this peculiar funerary practice typical of some monasteries in Northern Italy in the $17^{\text {th }}$-early $18^{\text {th }}$ century. In addition, from a more general point of view, this case, when compared with specific literature, clearly shows how the environment where the body is located plays a fundamental role in the selection of the fauna associated with the body. In fact, the sealing stone placed at the entrance of the putridarium impeded the colonisation by blowflies but it did not prevent the access to the crypt, while allowing, the body colonisation by smaller species (eg. Phoridae) belonging to taxa specialised in buried/concealed and indoor environments. These observations are useful not only in the reconstruction of events that happened in archaeological or historical contexts, but they can also be used in modern forensic cases when cadavers are buried or concealed in enclosed spaces.

\section{Acknowledgements}

We sincerely thank Prof. Otero Gonzalez Jose Carlos (Santiago de Compostela, Spain), Dr. Adriano Zanetti (Verona, Italy) for the identification of the specimens respectively in the families Cryptophagidae and Staphylinidae, and Rohan Raval (University of Huddersfield) for the English revision. We are grateful to the editor and the two anonymous reviewers for providing useful comments on the first version of the paper. This work was partially funded by the Leverhulme Trust Doctoral Scholarship program.

\section{References}

Amadei A., Fornaciari G. (1995) Le mummie della chiesa di S. Maria della Grazia in Comiso. Archivio per l'Antropologia e la Etnologia 125:141-163 
Amendt J., Campobasso C.P., Goff M.L., Grassberger M. (Editors) (2010) Current concepts in forensic entomology. Springer, Dordrecht

Betz O., Irmler U., Klimaszewski J. (Editors) (2018) Biology of Rove beetles (Staphylinidae): Life History, Evolution, Ecology and Distribution. Springer, Cham

Bhadra P., Hart A.J., Hall M.J.R. (2014) Factors affecting accessibility to blowflies of bodies disposed in suitcases. Forensic Science International 239:62-72

Blackwelder R.E. (1936) Morphology of the coleopterous family Staphylinidae. Smithsonian Miscellaneous Collections Vol 94 (13), Washington

Bohac J. (1999) Staphylinid beetles as bioindicators. Agriculture, Ecosystems and Environment 74:357-372

Bourel B., Tournel G., Hédouin V., Gosset D. (2004) Entomofauna of buried bodies in northern France. International Journal of Legal Medicine 118:215-220

Bugelli V., Forni D., Bassi L.A., Di Paolo M., Marra D., Lenzi S., Toni C., Giusiani M., Domenici R., Gherardi M., Vanin S. (2015) Forensic entomology and the estimation of the minimum time since death in indoor cases. Journal of Forensic Sciences 60:525-531

Campobasso C.P., Disney R.H.L., Introna F. (2004) A case of Megaselia scalaris (Loew) (Dipt., Phoridae) breeding in a human corpse. Aggrawal's Internet Journal of Forensic Medicine and Toxicology 5:3-5

Campobasso C.P., Introna F. (2001) The forensic entomologist in the context of the forensic pathologist's role. Forensic Science International 120:132-139

Couri M.S., Cunha A.M., Souza S.M.F.M., Laeta M. (2009) Ophyra capensis (Wiedemann) (Diptera, Muscidae) found inside the esophagus of a mummy in Lisbon (Portugal). Papéis Avulsos de Zoologia 49:87-91

Davis T.S., Crippen T.L., Hofstetter R.W., and Tomberlin J.K. (2013) Microbial volatile emissions as insect semiochemicals. Journal of Chemical Ecology 39:840-859

Dirrigl F.J., Greenberg B. (1995) The utility of insect remains to assessing human burials: a Connecticut case study. Archaeology of Eastern North America 23:1-7

Disney R.H.L. (1989) Scuttle flies: the Phoridae (Genus Megaselia). The Royal Entomological Society Handbooks, Vol 10. Royal Entomological Society, London

Disney R.H.L. (1994) Scuttle flies: the Phoridae. Chapman and Hall, London

Disney R.H.L. (2008) Natural history of the scuttle fly, Megaselia scalaris. Annual Review of Entomology 53:39-60

Easton A.M., Smith K.G.V. (1970) The entomology of the cadaver. Medicine, Science and the Law 10:208-215

Fabbri P.F. (2001) Sepolture primarie, secondary e ossari: esempi dal cimitero medieval di Roca Vecchia (Lecce). Rivista di Antropologia 79:113-136 
Farella F. (1982) Cenni storici della Chiesa e delle catacomb dei cappuccino di Palermo. Edizioni Fiamma Serafica, Palermo

Feng D.X., Liu G.C. (2012a) Morphology of immature stages of Dohrniphora cornuta (Bigot) (Diptera: Phoridae). Microscopy Research and Technique 75:1528-1533

Feng D.X., Liu G.C. (2012b) Morphology of immature stages of Megaselia spiracularis Schmitz (Diptera: Phoridae). Microscopy Research and Technique 75:1297-1303

Fornaciari A., Giuffra V., Pezzini F. (2010) Secondary burial and mummification practices in the Kingdom of the two Sicilies. Mortality 15:223-249

Fornaciari G., Giuffra V., Marinozzi S., Picchi M.S., Masetti M. (2009) "Royal" pediculosis in Renaissance Italy: Lice in the mummy of the King of Naples Ferdinand II of Aragon (1467-1496). Memórias do Instituto Oswaldo Cruz 104:671-672

Fornaciari, G (2018) Informazioni nascoste nelle mummie, nelle sepolture e negli antichi ambienti abitativi: l'archeoentomologia medica degli insetti vettori. Atti Dell'accademia Nazionale Italiana di Entomologia. Rendiconti 65:215-220

Giordani G., Grzywacz A., Vanin S. (2018) Characterization and identification of puparia of Hydrotaea Robineau-Desvoidy, 1830 (Diptera: Muscidae) from forensic and archaeological contexts. Journal of Medical Entomology 20:1-10

Goff M.L. (1991) Comparison of insect species associated with decomposing remains recovered inside dwellings and outdoors on the island of Oahu, Hawaii. Journal of Forensic Science 36:748-53

Greenberg B. (1985) Forensic Entomology: Case Studies. Bulletin of the Entomological Society of America 31:25-28

Greenberg B., Wells J.D. (1998) Forensic use of Megaselia abdita and M. scalaris (Phoridae: Diptera): case studies, development rates, and egg structure. Journal of Medical Entomology 35:205-209

Gregor F., Rozkošný R., Barták M., Vaňhara J. (2002) The Muscidae (Diptera) of Central Europe. Vol 107. Masaryk University, Brno.

Grzywacz, A. (2013) Third instar larva morphology of Hydrotaea cyrtoneurina (Zetterstedt, 1845) (Diptera: Muscidae) - a species of forensic interest. Polish Journal of Entomology 82:303-315

Grzywacz, A., Lindström A., Hall M.J.R. (2014) Hydrotaea similis Meade (Diptera: Muscidae) newly reported from a human cadaver: a case report and larval morphology. Forensic Science International 242:34-43

Grzywacz, A., Ogiela J., Tofilski A. (2017a) Identification of Muscidae (Diptera) of medico-legal importance by means of wing measurements. Parasitology Research 116:1495-1504 
Grzywacz, A., Wallman J. F., Piwczyński M. (2017b) To be or not to be a valid genus: the systematic position of Ophyra R.-D. revised (Diptera: Muscidae). Systematic Entomology 42:714-723

Gunn A., Bird J. (2011) The ability of the blowflies Calliphora vomitoria (Linnaeus), Calliphora vicina (Rob-Desvoidy) and Lucilia sericata (Meigen) (Diptera: Calliphoridae) and the muscid flies Muscina stabulans(Fallen) and Muscina prolapsa (Harris) (Diptera: Muscidae) to colonise buried remains. Forensic Science International 207:198-204

Huchet J.B. (2013) L'archéo-entomologie: les insectes nécrophages associés aux soldats de Carspach, pp. 109-110. In B. Schnitzler and M. Landolt (eds.) A l'est $d u$ nouveau! Archéologie de la Grande Guerre en Alsace et en Lorraine. Musée de Strasbourg, collection Archéologie, Strasbourg.

Huchet J.B. (2014) Insect remains and their traces: Relevant fossil witnesses in the reconstruction of past funerary practices. Anthropologie 52:329-346

Huchet J.B. (1996) L'archeoentomologieFuneraire: une approche originale dans l'interprétation des sépultures. Bulletins et mémoires de la Société d'Anthropologie de Paris 8:299-311

Huchet J.B. (2014) L'archéoentomologie funéraire. In: Charabidze D., Gosselin M., eds. Insectes, cadavres et scènes de crime, Principes et applications de l'entomologie médico-légale. Louvain-la-Neuve: De Boeck 201-224

Huchet J.B., Greenberg B. (2010) Flies, Mochicas and burial practices: a case study from Huaca de la Luna, Peru. Journal of Archaeological Science 37:2846-2856

Huchet J.B., Callou C., Lichtenberg R., Dunand F. (2013a) The dog mummy, the ticks and the louse fly: Archaeological report of severe ectoparasitosis in Ancient Egypt. International Journal of Paleopathology 3:165-175

Huchet J.B., Pereirad G., Gomye Y., Philipsf T.K., Alatorre-Bracamontesg C.E., Vásquez-Bolañosg M., Mansillah J. (2013b) Archaeoentomological study of a preColumbian funerary bundle (mortuary cave of Candelaria, Coahuila, Mexico). Annales de la Société entomologique de France 49:277-290

Huckett, H.C. (1954) A Review of the North American species belonging to the genus Hydrotaea Robineau-Desvoidy (Diptera, Muscidae). Annals of the Entomological Society of America 47:316-342

Kirby W. (1826) Systematic treatments In: Kirby, W., Spence, W. (Eds.) An introduction to entomology: or elements of the natural history of insects: with plates, Vol 4. Longman, Rees, Orme, Brown and Green, London

Kočárek P. (2003) Decomposition and Coleoptera succession on exposed carrion of small mammal in Opava, the Czech Republic. European Journal of Soil Biology 39:3145 
Leschen R.A.B. (1996) Phylogeny and revision of the genera of Cryptophagidae (Coleoptera: Cucujoidea). The University of Kansas Science Bulletin 55: 549-634

Licata M., Rossetti C. (2017) The Skeleton of the Azzio's Crypt (Northern Italy): A forensic case in an archaeological context. The American Journal of Forensic Medicine and Pathology 38:272-274

Lo Pinto S., Giordani G., Tuccia F., Ventura F., Vanin S. (2017) First record of Synthesomyia nudiseta (Diptera: Muscidae) from forensic cases in Italy. Forensic Science International 276:e1-e7

Lohse, G.A. (1964) Staphylinidae I. (Micropeplinae bis Tachyporinae) In: Freude, H., Harde, W., Lohse, G.A. (Eds.), Die Kafer Mitteleuropas. Goecke and Evers, Krefeld, $364 \mathrm{pp}$.

Lohse, G.A., Benick, G., Likovsky, Z. (1974) Staphylinidae II. (Hypocyphtinae bis Aleocharinae). In: Freude, H., Harde, W., Lohse, G.A. (Eds.), Die Kafer Mitteleuropas. Goecke and Evers, Krefeld, 304 pp.

Martín-Vega D., Hall M.J.R., Simonsen T.J. (2016) Resolving confusion in the use of concepts and terminology in intrapuparial development studies of cyclorrhaphous Diptera. Journal of Medical Entomology 53:1249-1251

Martn-Vega D., Gmez-Gmez A., Baz A. (2011) The "Coffin Fly" Conicera tibialis (Diptera: Phoridae) breeding on buried human remains after a postmortem interval of 18 years. Journal of Forensic Sciences 56:1654-1656

Masetti M., Gabrielli S., Menconi M., Fornaciari G. (2008) Insect remains associated with the mummy of Cardinal Giulio della Rovere, Archbishop of Ravenna (1533-1578). In: Atoche Peña P., Rodríguez Martín C., Ramírez Rodríguez M.A. (Eds.) Mummies and science: world mummies research. Proceedings of the VI World Congress on Mummy Studies, Teguise, Lanzarote, Islas Canarias pp.379-385. Academia Canaria de la Historia, Santa Cruz de Tenerife

Mégnin J.P. (1894) La faune des cadavres. Encyclopedie Scientifique des AidMemoire. Masson, Gauthier-Villars et Fils, Paris

Morrow J.J., Baldwin D.A., Higley L., Piombino-Mascali D., Reinhard K.J. (2015) Curatorial implications of Ophyra capensis (Order Diptera, Family Muscidae) puparia recovered from the body of the Blessed Antonio Patrizi, Monticiano, Italy (Middle Ages). Journal of Forensic and Legal Medicine 36:81-83

Morrow J.J., Myhra A., Piombino-Mascali D., Lippi D., Roe A., Higley L., Reinhard K.J. (2016) Archaeoentomological and archaeoacarological investigations of embalming jar contents from the San Lorenzo Basilica in Florence, Italy. Journal of Archaeological Science: Reports 10:166-171

Newton, A. F., Jr. (1990) Insecta: Coleoptera, Staphylinidae, adults and larvae. In: Dindall, D.L. (Ed.), Soil Biology Guide. Wiley, New York 1137-1174 
Nystrom K.C., Goff A., Goff M.L. (2005) Mortuary behaviour reconstruction through Palaeoentomology: a case study from Chachapoya, Perú. International Journal of Osteoarchaeology 15:175-185

Palla F., Sineo L., Manachini B. (2011) Bacteria, fungi and arthropod pests collected on modern human mummies. Journal of Entomological and Acarological Research 43:69-7

Panagiotakopulu E. (2001) New records for ancient pests: archaeoentomology in Egypt. Journal of Archaeological Science 28:1235-1246

Panagiotakopulu E. (2004) Dipterous remains and archaeological interpretation. Journal of Archaeological Science 31:1675-1684

Panagiotakopulu E., Buckland P.C. (2012) Forensic archaeoentomology - an insect fauna from a burial in York Minster. Forensic Science International 221:125-130

Pastula E.C., Merritt R.W. (2013) Insect arrival pattern and succession on buried carrion in Michigan. Journal of Medical Entomology 50:432-439

Pezzini F. (2006) Pratiche di mummificazione e scolatura dei corpi in Italia meridionale in Eta' Moderna. Atti del Convegno Medicina nei Secoli, Roma

Pushkin S.V. (2015) Environmental group Necrophilous and Necrobionts Beetles (Insecta; Coleoptera) of the south of the Russia. Entomology and Applied Science Letters 2:1-9

Reibe S, Madea B. (2010a) Use of Megaselia scalaris (Diptera: Phoridae) for postmortem interval estimation indoors. Parasitology Research 106:637-40

Reibe S, Madea B. (2010b) How promptly do blowflies colonise fresh carcasses? A study comparing indoor with outdoor locations. Forensic Science International 195:527

Skidmore P. (1985) The biology of the Muscidae of the world. Dr. W. Junk Publishers, Dordrecht

Smith K.G.V. (1986) A manual of forensic entomology. Ithaca: Comstock Publishing Associates, Cornell University Press

Sukontason K. L., Ngern-Klun R., Sripakdee D., Sukontason K. (2007) Identifying fly puparia by clearing technique: application to forensic entomology. Parasitology Research 101:1407-1416

Sukontason K.L., Boonsriwong, W., Siriwattanarungsee, S., Piangjai S., Sukontason K. (2006) Morphology of puparia of Megaselia scalaris (Diptera: Phoridae), a fly species of medical and forensic importance. Parasitology Research 98:268

Trumble J.T, Pienkowski R.L. (1979) Development and survival of Megaselia scalaris (Diptera: Phoridae) at selected temperatures and photoperiods. Proceedings of the Entomological Society of Washington 81:207-10 
Turchetto M., Vanin S. (2004) Forensic evaluations on a crime case with monospecific necrophagous fly population infected by two parasitoid species. Anil Aggrawal's Internet Journal of Forensic Medicine and Toxicology 5:12-18

Vanin S. (2012) Archeoentomologia funeraria: risultati e prospettive dallo studio delle mummie di Roccapelago. In: Roccapelago e le sue mummie: studio integrato della vita di una piccola comunità dell'Appennino tra XVI e XVIII secolo. Modena: Academy Editions 225-229

Vanin S., Turchetto M., Galassi A., Cattaneo C. (2009) Forensic entomology and the archaeology of war. Journal of Conflict Archaeology 5:127-139

Vanin S., Huchet J.B. (2017) Forensic Entomology and Funerary Archaeoentomology, pp. 167-186. In: E. M. Schotsmans, N. Márquez-Grant and S. L. Forbes (eds.), Taphonomy of Human Remains: forensic analysis of the dead and the depositional environment. Wiley, 545 Manhattan

Verheggen F., Perrault K.A., Megido R.C., Dubois L.M., Francis F., Haubruge E., Forbes S.L., Focant J.F., Stefanuto P.H. (2017) The odor of death: An overview of current knowledge on characterization and applications. BioScience 67: 600-613

Wyss C., Cherix D. (2013) Traité d'entomologie forensique: les insects sur la scène de crime. Presses Polytechniques et Universitaires Romandes, Lausanne. 